\title{
Translation Strategies of the Non-Native Odia Translators (1807-1874)
}

\author{
RAMESH C MALIK
}

Translation strategy means a plan or procedure adopted by the translators to solve the translation problems. The present paper is to highlight on the translation strategies of the non-native Odia translators during the colonial period (1807-1874). First of all, those translators who were non-residents of Odisha and had learnt Odia for specific purposes are considered non-native Odia translators. The first name one of the Odia translators is William Carey (1761-1834), who translated the New Testament or Bible from English to Odia that was subsequently published by the Serampore Mission Press Calcutta in 1807. A master craftsman of Christian theology and an Odia translator of missionary literature, Amos Sutton (1798-1854), who translated John Bunyan's (1628-1688) the Pilgrim's Progress (1678) to Odia under the titled swargiya jātrira brutānta in 1838. Sutton served as an Odia translator under the British government. His religious, literary, and linguistic contributions to Odia language and literature are to be studied for making a concrete idea about the development of Odia prose. In the era of Odia translation discourse, his translations deserve to be studied in the theoretical frame of translation strategies.

In this paper, the following translation strategies like linguistic strategies, literal translation strategy, lexical alteration strategy, deletion, exoticism and cultural transposition strategies are predominately adopted by the translators. Since the objectives of the SLTs were to promote religious evangelization and second language learning, the translation strategies tried to preserve the religious and pedagogical fidelity rather that textual fidelity in the translated texts.

Keywords: translation strategy, missionary literature, non-native odia translators, exoticism and cultural transposition

\section{Introduction}

Translation is one of the indispensable tools for the growth of a language, literature, and socio-cultural transactions among different classes of people. Language and translation are both socially and linguistically recognized as a communicative model of the two different linguistic communities. That is why translation is often considered as one of the oldest literary genres. 
Needless to say, a study of 'translation strategy' is a study of 'translation process operator' which deals with the translators' mental operative knowledge system towards the linguistic, extra-linguistic, and literary issues of translations.

According to Chesterman (2002: 57), "the term 'strategy' is then used to describe well established procedures, proven methods of solving particular kinds of problems and reaching the desired goal". Again, it has been noted by Chesterman (2005) that "the term 'strategy' itself often used in different ways in translation studies, but a variety of other terms can be used to mean the same thing: 'procedures', 'techniques of adjustment', 'transformation', and transfer operations' and etc"(quoted in Kearns 2009: 282). Molina and Alibir (2002: 508) define "translation strategies are the procedures (conscious or unconscious, verbal or non-verbal) used by the translator to solve problems that emerge when carrying out the translation process with a particular objective in mind". The translation strategies adopted by the non-native Odia translators will be discussed under the theoretical preliminaries of the translation strategy.

There are always several overt and covert factors which lead to the progress of the translation activities in a multilingual and multicultural country like India. Among them, language learning through the GrammarTranslation method is found to be very significant during the colonial period. Thomas James Maltby, a British official, who served as an assistant collector of Ganjam district under Madras Presidency, wrote A Practical Handbook of Uriya or Odiya Language which was published in 1874. Maltby (1986: x) categorically mentioned in its preface that "it is hoped that this book, although professedly for Europeans learning Uriya (Oriya), may also be found useful to Uriyas learning 0English". For the purposes of language learning and teaching, Maltby included a small collection of moral fables in his book. The fifth chapter of the book documented around thirty moral fables in English along with their Odia translations in order to facilitate learning and teaching both the languages through the Grammar Translation Method (GTM).

Translation is used as a one of the important activities during the colonial period. Socio-cultural interventions of the linguistic community and colonial policy provided patronage to the translation activities. The Western culture, literature, and religious thoughts were transplanted by the non-native Odia translators on the soil of Odisha. However, their intentions were confined to religious evangelization, language teaching, and learning, ultimately, their translation practice attempted to canonize the Odia literature in various ways. These translators not only rendered the European literature into Odia, but also introduced new styles of writing, new literary genres, literary techniques, linguistic interpretations. Therefore, their translations strategies are crucial to be discussed for exploring the intention behind translating the texts.

William Carey, Amos Sutton, and Thomas James Maltby are the most popular non-native Odia translators. Sutton and Maltby never detailed their 
translation plans and procedures either in any preface to their translations or in any personal documents. On the other hand, William Carey, in his biographical note, admits that he was involved with various translation activities. According to Eustace Carey (1836), William Carey served as a biblical translator under the Baptist Missionary Society of Calcutta and a teacher of Oriental languages at Fort William College of Calcutta in 1801. His interest in learning Oriental languages inspired him to translate the Bible into all the major languages and dialects of India including some of the languages of South Asia. For translating the biblical literatures, he established a printing press named the Serampore Mission Press at Serampore with the help of his friends, Joshua Marshman (1768-1837), and William Ward (1769-1823) in 1800. For the purpose of the Bible translation, these non-native trios started the biblical translation industry at Serampore. The printing press was set up under the supervision of William Ward along with a native of Bengal named Panchanan Karmakar who served there as a punchcutter. This biblical translation industry flourished with his sincere efforts and hard work. With the close association of his friends and native pundits of Indian languages, Carey could complete translation of the Bible into almost all major Indian languages.

As Chrysostom Arangaen and John Philiose (1992: 11) point out: "the pundits of Fort William College assisted Carey not only in translating the Bible but also in the prose style of their respective languages. Thus, Carey was instrumental in producing 7 grammars, 4 dictionaries, 13 polyglot vocabularies besides 132 pedagogically oriented books". Therefore, Carey is regarded as a famous Oriental biblical translator and also acknowledged one of the grammarians and teachers of Indian languages. He served as a professor of three Oriental languages, such as Sanskrit, Bengali, and Marathi at Fort William College and there he wrote the grammar of Sanskrit, Bengali, Marathi, and Telugu. The New Testament of Odia Bible was the one which was translated under the supervision of Carey at the end of 1807 and then revised in 1811 and 1814 subsequently.

Apart from these activities, the translation strategies which have been adopted by Carey are mentioned by F.A. Cox, a missionary historian. His book History of the Baptist Missionary Society (from 1792 to 1842) cites the crucial information about Carey's translation strategies and especially his experiences on the Odia Bible translating. It is necessary to mention Carey's experiences and also his comments on the Odia Bible translation that present the idea for understanding of the non-native Odia translation strategies used during the same period. Carey's translation strategies have been discussed by Cox by drawing on the former's personal letters which had been sent to Sutcliff. In one of his letters Carey proclaimed:

"We do not want the vain name of the men, who have translated the scriptures into this or that language, but we do want the thing to be done; and we have not yet seen the least probability of any one's 
doing it besides ourselves. We, however, wish everyone to try and do all he can; this is no reason why we who have begun before them all should, to compliment them, throw away all which we have done. It is, perhaps, necessary to obviate the objection founded in our employing natives to assist us, which represents it as if no advantage could be obtained from employing a 'wicked Brahmin'. In the first place, they themselves who make this complaint do the same, and must do it. But, in the second place, we never print a sentence without examining it and seeing it through and through. Brother Marshman does this with the Chinese. I translate, and write out with my own hand, the Bengalee (Bengali), Hindoostanee (Hindustani), and Sunskrit (Sanskrit). The two latter (New Testament) I translate immediately from the Greek by brother Marshman and myself, as is the Bengalee (Bengali) with the Hebrew. I compare the Mahrattta (Marathi) and the Orissa (Oriya), to the best of my power, and can say that I believe these translations to be good ones. I believe, likewise, that I am as able to judge of them as any person now in India (I am a fool; they have compelled me). We do employ natives, and avail ourselves of all the help we can; but we never give up our judgment, any language, nor ever intend to do so. I have no doubt but there are mistakes, arising from various causes, which will be gradually corrected in future editions; but I am persuaded that there are no capital errors in them. In this way we mean to go on as long as we can, without giving up anything which we have begun" (Cox 1842: 171-172).

This statement clearly reflects Carey's biblical translation strategies and his evaluation techniques. There is another letter by Carey send to Dr Ryland on October 14, 1815 in which he acknowledged about the biblical translation strategies and his views about the native pundits who helped in translating the scriptures into their respective languages. The most significant translation procedures were:

"The native pundits write out the rough copy of the translation into their respective languages; some translating from the Bengali, others from the Hindustani, and others from Sanskrit, as they are best acquainted with them. They consult with one another, and other pundits who have been employed for several years in correcting the press copy, and who almost know the scriptures by heart. They, therefore, from the idioms; after which I examine and alter the whole where necessary, and upon every occasion have men born and brought up in the countries themselves to consult. The number of these languages far exceeds what I thought it till very lately, for till lately I, like almost everyone else, thought all the north and west of India to be occupied by the Hindi or Hindustani, but I now doubt whether any country be exclusively so. What have hitherto been 
accounted verities of the Hindustani and vulgar verities of jargon, are in reality distinct languages, all derived, it is true, from the same source, the Sanskrit, but so differently terminated and inflected as to make them unintelligible to the inhabitants of the surrounding countries. The uniformity of the words in all these languages, makes it comparatively easy for me to judge of the correctness of the translations, and makes that quite possible which to one unacquainted with Sanskrit and the mutation of words in the current languages, would be impossible" (quoted in Carey 1836: 539).

This extract presents the general ideas about the biblical translation procedures used for Indian languages and how the native pundits' judgments were strictly followed for translating of the texts into their languages.

There is another statement about missionary translation strategy which has been documented by Pundit Nilakantha Das, who explained a scene in his autobiography with reference to the missionary evangelization of Odisha and the translation problems of biblical scriptures into Odia as well.

His explanations on the missionary translation strategy especially translating Bible into Odia represent the strategy of the decision of a translator while translating expressions like jisu sisumānaku sukha pāānti (Jesus adores the children) into Oriya by a Christian missionary. The same translation was examined by the Reverend following an empirical method of etymological clarification.

The Reverend asked a carpenter, "What do you mean by sisu?"

The carpenter answered, "It is a type of black wood like kendu".

The Reverend showing a small child, "How do you call him?"

He replied, pilā.

The Reverend knew sukha means änanda or bhoga (happiness, pleasure), so he did not like sukha-päiba where he discovered a faithful translation of English "love" is prema-karibā. Thereafter he corrected the sentence and made it like jisu pilāmānaku premakaranti (Jesus loves the Children) (Das 2003:46).

The earlier sentences have been changed according to rules of Odia along with the words like sisu > pilā and sukha pāānti > prema karanti. This is an evidence of the non-native Odia translators' translation strategy wherein the translator emphasizes the process of domestication rather than foreignization. These are not the only translation strategies have been adopted by the nonnative Odia translators. The following translation strategies like linguistic strategies, strategies for translating proper names, exoticism and cultural transportation, and transliteration will be discussed in this paper. 


\section{Linguistic Strategies}

The linguistic translation strategies primarily deal with the functions of the SL words, phrases, expressions, idioms and proverbs and sentences in the TT. While creating the syntactic and semantic approximations between two different words, phrases, expressions, idioms, and sentences, the non-native Odia translators have often used the following translation strategies: literal translation, lexical alteration, deletion, transposition, and lexical creation.

\section{Literal Translation Strategy}

Literal translation is a widely used translation strategy. Most of the translation critics have discussed the main functions of literal translation and some of them have distinguished the literal from the other types of translation. Vinay and Darbelnet (1995: 33-34) define "literal translation is the direct transfer of a SL text into a grammatically and idiomatically appropriate TL text in which the translators' task is limited to observing the adherence to the linguistic servitudes of the TL". According to Catford (1965: 25), "literal translation lies between these extremes; it may start, as it were, from a word-for-word translation, but make changes in conformity with TL grammar (e.g. inserting additional words, changing structures, at any rank, etc.); this may make it a group-group or clause-clause translation". Thus Catford holds that literal translation stands between word-for-word and free translation.

Basil and Mason (1996: 219) define "literal translation: a rendering which preserves surface aspects of the message both semantically and syntactically, adhering closely to source text mode of expression". The main purpose of literal translation is to express the fidelity of SL expressions with their intelligibility in the TL. Nida (1961: 12) argues that "the literal translation can be called as 'concordant', and makes an immediate appeal to those uniformed about the problems and principles of linguistic usage. But no two languages are similar in terms of their words or grammatical usages, and such a literal type of translation actually distorts the facts of a language rather than reveals them". Newmark (1988: 68) states:

"Word-for-word translation transfers SL grammar and word order, as well as the primary meaning of all the SL words, into the translation, and it is normally effective only for brief simple neutral sentence. In one-to-one translation, a broader form of translation, each SL words has a corresponding TL words, but their primary (isolated) meaning may differ. Thus in passer un examen - 'take an exam', the two verb couplets can be said to correspond with each other, but out of context, they are not semantic equivalents. Since, one-to-one translation respects collocation meaning, which are the most powerful contextual influence on translation, it is more common than word-for-word translation whereas literal translation goes beyond one-to-one translation (...). Literal translation ranges 
from one word to one word through group to group, collocation to collocation, clause to clause, and sentence to sentence".

Further, he clarifies " literal translation above the word level is the only correct procedure if the SL and TL meaning correspond, or correspond more closely than any alternative; that means that the referent and the pragmatic effect are equivalent, i.e. that the words not only refer to the same 'thing' but have similar associations and appear to be equally frequent in this type of text; further, that the meaning of the SL unit is not affected by its context in such a way that the meaning of the TL unit does not correspond to it. Normally, the more specific or technical a word, the less it is likely to be affected by its context" (ibid.).

Hatim and Munday (2004: 344) define literal translation as "a rendering which preserve aspects of the message both semantically and syntactically, adhering closely to ST mode of expression" which means it is a kind of translation strategy towards SL. In this context, Ivir (1987: 39) makes some observations on literal translation which are "often regarded as the procedure for filling of the cultural and lexical gaps in translation and, together with borrowing, is the commonest method of cultural transference and spread of influence from one culture into another". Thus, literal translation is a very commonly used translation strategy by all translators. So there is no hesitation to state that this strategy has been used by the non-native Odia translators especially while translating the religious texts and moral fables into Odia. There are lots of examples of this strategy in the translations by Carey, Sutton, and Maltby.

(1) SL: In the beginning God created the Heaven and the Earth (Genesis 1.1, The Holy Bible Revised Version, Standard American Edition). TL: prathamare iswara swarga o pruthwi srujana kale (Carey 1807:1). GL: at first /god / heaven / and / earth / created.

(2) SL: And God called the light Day, and the darkness he called night (Genesis 1.5).

TL: iswar diptira nāma dibasa rakhile o andhārara nāma rātri (Carey 1807: 1).

GL: god / light's / name / day/ put / and / dark's /name / night

(3) SL: And the Earth was waste and void (Genesis 1.2).

TL: pruthwi sunya o asthirakāra thilā (Carey 1807: 1)

GL: earth / empty / and / unstable-shaped / was

These examples clearly show how Carey has adopted the literal translation strategy in his translation of the Bible. He tried to bridge the cultural gaps between the two languages by closing translating the items of the SL to the TL. For example, the SL religious and culture-specific words: god, heaven, and earth have been rendered into Odia as same grammatical category, i.e. iswara, swarga, and pruthvi which are common in Odia. It is a fact that the 
religious concepts of Christianity are difficult to translate to languages of other religious and cultural contexts. Therefore, Carey frequently adopted literal translation strategy for the extra-linguistic expressions of the Bible.

All the characters and consequences of the Bible are composed with particular theological imaginations and doctrines. It may be a decision of the translator to adopt the literal translation strategy for such expressions and find equivalents and contextual functions in TL.

Like Carey, Amos Sutton often adopted the literal strategy for translating the theological doctrines of missionary evangelization.

(4) SL: Then said Evangelist .... (Bunyan 1670/1968: 10)

TL: tebe mangaLapracāraka pacārile (Sutton 1838: 04)

GL: then/ evangelist / asked...

(5) SL: A bird in the hand is worth two in the bush (Bunyan 1670/1968:

30)

TL: banare dui pakhiru hastagata eka pakhi bhala (Sutton 1838: 45)

GL: in the forest/ two/ from bird/ in hand/ one/ bird/ good

These two examples are translated literally into Odia. In example-4, the SL culture specific word Evangelist is literally rendered in Odia as mangalapracāraka which means 'a welfare-preacher' (who tries to persuade other to accept Christanity, especially by travelling around the country and holding the Bible). In example-5, SL idiom "a bird in hand is worth two in the bush" is translated literally into Odia.

A few more SL idioms are translated following the same translation strategy.

(6) SL: gird up his loins. (Bunyan 1670/1968: 36)

TL: aNTabāndhi (Sutton 1838: 58)

GL: by tying the waist

(7) SL: a roaring lion (Bunyan 1670/1968: 38)

TL: garjita singha (Sutton 1838: 61)

GL: roared lion

There are few examples which can be taken into consideration as literal translation when two characters are performing a conversation between them in a dialogue form. There is a scene which portrays the Christian faiths, beliefs and ideologies. While translating such a scene into Odia, the translator has adopted the literal translation strategy.

(8) SL: Pliable: and do you think that the words of your book are certainly true? (Bunyan 1670/1968: 13)

TL: cancala kahile tumbhara pustaka madhyare jāha achi tāha niscaya satya eha ki tumbhe jāna (Sutton 1838: 10)

GL: The quick/said/your book/ inside/ whatever/is/that/certainly/true/ this/you/know 
SL: Christian: Yes, verify; for it was made by Him that cannot lie. (Bunyan 1670/1968: 13)

TL: khrisTian kahile je hāM āmbhe jāni kipāna satyabādi eswara e pustaka racanā kari achanti (Sutton 1838: 10)

GL: Christian/told/that/yes/I/ having known/why/truthful/God/this/book /has written

SL: Pliable: Well said; what thinks are they? (Bunyan 1670/1968: 13)

TL: cancala kahile bhala kahile tahiMre ki ki lekhā achi (Sutton 1838:

10)

GL: The quick/ said/ well/spoke/ in that/ what/what/ writing/is

Sutton was acquainted with the literal translation strategy. These two examples are illustrative of literal translation wherein the translator makes syntactic and semantic adjustments between the two languages. Few more examples are given below:

(9) SL: Now, said Christian, let me go hence. (Bunyan 1670/1968: 33)

TL: au khrisTian kahile ehikhyaNe āmbhaku esthānaru jibāku dia (Sutton 1838: 50)

GL and/ Christian/ said/ now/ to me / from this place/ to go/give

(10) SL: These pilgrims are come from the City of Destruction... (Bunyan 1670/1968: 155)

TL: ehi jātri lokamāne sarbanāsa nāmaka nagararu aile... (Sutton 1838: 329)

GL: this/ traveller/ people/ destruction/ namely/ from city / came.

In the above examples, the SL nouns Christian, Pilgrim's, the City of Destruction and verbs go and come have been translated as the same grammatical units like nouns: khristian, jatrilokamane, sarbanasa namaka nagarara and verbs: jiba, aile in Oriya.

Literal translation is normally used for Second Language learning. In this context, a few examples can be cited from translation of nitikatha (moral fable) by T. J. Maltby, who has expressed his opinion in the preface: "the chief object which I have had in compiling this Handbook is to supply an existing want in a practical shape, as with the exception of Dr. Sutton's Introduction to Uriya (Odia), which was published about a generation ago, there is no book I know of, that will assist the Englishman in learning the Uriya language". For the purpose of language learning and teaching Maltby has adopted the literal translation strategy.

(11) SL: A mosquito sat on a bull's horn, and, in its pride imagining that it was heavy, said to the bull: (Maltby 1874/1986: 154)

TL: gotie masā eka saNDha srunga upare basi ahankarare āpaNāku bhari bujhi saNDhaku kahilā (Maltby 1874/1986: 155)

GL: a / mosquito / one / bull / horn / sitting on / proudly/ himself / heavy / understanding / to bull/said 
(12) SL: A number of frogs were sitting in a large paddy field (Maltby 1874/1986: 178)

TL: eka bruhat biLare aneka bengara basati thāi (Maltby 1874/1986:

179)

GL: one/ large/ in field/ many/frogs/settlement/are

(13) SL: A lion becoming weak from old age was no longer able to capture living animals (Maltby 1874/1986: 166).

TL: eka singha bārdhakya heturu jarāgrasta hoi kauNasi jiba jantura pāridhi kari pāru na thāe (Maltby 1874/1986: 167)

GL: a / lion / due to old age /sick / being / any / of animal / hunting / unable to do

(14) SL: Two cocks had a fight about something (Maltby 1874/1986:

174).

TL: dui kukuDā kauNasi drabya lāgi juddha kale (Maltby 1874/1986: 175)

GL: two/ cock/for something/ fight/did

(15) SL: "Ho! Peasants, a tiger has got in amongst my cattle; come to my rescue"(Maltby 1874/1986: 180).

TL: he casāmāne āmbha goru madhyare goTie byāghra āsi-achi, tumbhemāne āsi rakhyā kara (Maltby 1874/1986: 181).

GL: oh /farmers/ my /cattle/ in middle/a/tiger/ has come /you / having come/save

The above mentioned examples are translated to Oriya following the principle of literal translation.

\section{Lexical Alteration Strategy}

The lexical alteration strategy has also adopted by the non-native Odia translators. There are a few examples in Sutton's Odia translation which can be discussed from this point of view.

(1) SL: O my dear wife said he, and you the children of my bowels, (Bunyan 1670/ 1968: 09)

TL: he āmbhara priya stri he āmbhara aurasa santāna (Sutton 1838:

02)

GL: oh /my/ dear/ wife/ oh/ my/ bowels/ children.

Translating metaphors as non-metaphors is an important point here. In this example, the SL expression "the children of my bowels" offers a metaphoric sense, but its Oriya translation ämbhara aurasa santāna is a non-metaphoric expression in the TL.

(2) SL: CHR: yes, very well. (Bunyan 1670/1968: 19)

TL: kshrisTan kahile: hāM sundara rupe dekhibāku pāi (Sutton 1838:

22)

GL: Christian/ said/ yes/ in beautiful form/getting/to see 
The SL expression very well has been translated to Oriya as sundara rupe which means 'in a beautiful shape' but the translator has altered the syntactic order of the SL in the TL by adding a verb phrase dekhibāku pāi (get to see) in order to clarify the meaning.

(3) SL: Once upon a time a deer ran away through fear of a hunter, and entered into a cave (Maltby 1874/1986: 152).

TL: kauNasi samayare goTie mruga byādha bhayare paLāi eka gartta bhitare prabesa helā (Maltby 1874/1986: 153).

GL: once/ in time /a / deer/ hunter/ in fear/having fled / a hole/ inside/ entered.

In this example, the SL word cave has changed to gartta (hole) in Oriya. Here, the lexical meaning of cave is entirely different from that of hole.

There are a few examples which demonstrate the idea about lexical alteration.

\section{Deletion}

There are certain decisions which a translator makes before actually starting the translation in response to such questions as 'What are the extra-linguistic features of the text'? 'What could be its equivalent effects in TT' and 'what could be the strategies for them in order to accommodate the TT readers'? Form these questions one can understand that translation of a literary text undergoes different processes such as domestication, foreignization, and manipulation, etc.

In this case, John Bunyan's The Pilgrim's Progress, originally written in 1670 and translated to Odia by Amos Sutton in 1838, reflects several translation strategies, such as adaptation, deletion, and transliteration.

Nida (1964:231) has laid down the following conditions for this purpose: (1) repetitions, (2) specification of references, (3) conjunctions, (4) transitional, (5) categories, (6) vocatives, and (7) formulae. Nida's conditions of deletion can be justified by giving examples from the translations of the non-native Odia translators.

There are some shorts of poems in the SL which are found totally deleted by the translator in the TL. Since it is a prose text, the translator does not render all poems in TT. There are also other examples in which the ST units get deleted in TT.

(1) SL: As $\boldsymbol{I}$ walked through the wildness of this world, $\boldsymbol{I}$ lighted on a certain place where was a Den, and $\boldsymbol{I}$ laid me down in that place to sleep: and as $\boldsymbol{I}$ slept $\boldsymbol{I}$ dreamed a dream. $\boldsymbol{I}$ dreamed, and behold, $\boldsymbol{I}$ saw a man clothed with rags, standing in a certain place, with his face from his own house, a book in his hand, and a great burden upon his back. $I$ looked, and saw him open the book and read therein; and as he read, he wept and trembled; and not being able longer to contain, he brake out with a lamentable cry , saying, " what shall I do? 
(Bunyan 1670/1968: 9).

TL: mahāranyarupa ehi jagatare bhramaNa karu karu eka parbatara guhāre ämbhe upasthita hoi sayana kari nidrāre paDiluM. tahiMre dekha chiNDābastra parihita a panara gruhaThāru bimukha, hātare khaNDe pustaka puNi prusThare eka bhāri bojha emanta eka janaku swapnajogare dekhiluM. anantare dekhuM dekhuM, se janaku pustaka phiTāi pāTha karibaku dekhiluM puNi pāTha karu karu, se krandana kari mohā kampamānahoile. adhika sahi na pāri se eka mohā bilāpa sabada kari āmbhe ki karibā ehi kathā kahi Dāka pakāile (Sutton 1838: 1).

In the SLT, the first person singular pronoun $\boldsymbol{I}$ has been used nine times where it occurs in TL three times; so six occurrences have been deleted in TL.

The above examples provide the attestation of deletion of SL materials in $T L$ due to the repetitions, specification of references, and conjunctions.

\section{Strategies for Translating Proper Names}

Proper names form a part of a language system which represent their special functions and accordingly they can be considered a separate group within the concerned language. According to Rosenhouse (1998: 245), "the lexical meaning of personal names and surnames indicate some physical, psychological or professional feature of the individual or a physical feature of his/her surrounding natural environment". Zabeeh (1968: 59) states that proper names are pragmatically used to identify, refer to, or distinguish a single person or object, or they may have all the three functions at the same time. On the other hand, "proper names may have connotations when applied to persons and places which are well-known to both the speaker and hearer, but in themselves, turn out of context, they often mean nothing at all" (Ullman 1972: 74). Therefore, translating proper names from one language to other definitely creates problems for the translators. In order to resolve these problems, translators adopt the following strategies: "either the name can be taken over unchanged from the ST to the TT, or it can be adopted to conform to the phonic or graphic characteristics of the TL" (Hervey \& Higgins 1992: 29). It can be noted here that for several centuries the practice has been to 'translate' or 'adapt' personal and place names. Hervey and Higgins observe that there are a few effective strategies for translating names, such as exoticism, transliteration, cultural borrowing, calque, communicative translation and cultural transplantation. Our task now is to find out the nonnative strategies of translating foreign proper names to Odia.

While translating the Pilgrims Progress into Odia, Sutton has adopted the following strategies for rendering the proper names.

\section{Exoticism and Cultural Transposition}

The convention now is to look at the names which have connotations in religious and imaginative literature. In this context, Newmark (1988: 215) 
suggests that "the best method is first to translate the word that underlines the SL proper names into the TL, and then naturalize the translated word back into a new SL proper name- but normally only when the character's name is not yet current among an educated TL readership". Sometimes the translators localize the foreign names in the TL matching with the native environments. Sutton has translated some such expressions by adopting the local geographical locations of Odisha, such as the king of glory (p.29) translated to Odia as gajapati rājā 'the Gajapati King' (p.43), and the king of this place (p.153) is rendered as puri madhyare mahārājā 'the King of Puri'.

Exoticism is used by a translator when "a TT translated in an exotic manner in one which constantly resorts to linguistic and cultural features imported from the ST into the TT with minimal adaptation, and which, thereby, constantly signals the exotic source culture and its cultural strangeness" (Hervey and Higgins 1992: 30). Exoticism is more or less a result of literal translation which does not allow any cultural transposition in TL. There are a few personal names which have been translated to Odia following their literal meanings: personal names such as evangelist (p.10) $>$ mangalapracāraka (p.04), obstinate (p.11) > Thentā (p.06), pliable (p.11) >cancala (p.06), Mr. Worldly Wiseman (p.17) > sansāra gyāni (p.16), legality (p.19) > byabasthanugata (p.21), goodwill (p.25)> paramangalechu (p.32), interpreter (p.28) > arthadāyaka (p.39), passion (p.30) > rāgasila (p.43), patience (p.30) > dharjyasila (p.43). Similarly place names are also translated in the same method: the city of Destruction (p.11) > dhwansaniya nagara (p.06), the town of Carnal Policy (p.17) > sāririka buddha nāmaka (p.16), Mount Zion (p.25) siyāna parbata (p.31), and the country of Beulah (p.149) > parisayana námaka desa (p.315). In order to domesticate the fictional character of the text, the translator has adopted such a translation strategy which is helpful to understand the physiological stimuli of the imaginary characters and as well ideas about the place names.

\section{Transliteration}

Transliteration is rendering of the phonic/graphic shape of SL names in a TL with the same patterns of spelling and pronunciation.

According to Catford (1965: 66), transliteration involves three steps: (1) SL letters are replaced by SL phonological units; this is the normal literate process of converting from the written to the spoken medium; (2) the SL phonological units are translated into TL phonological units; (3) the TL phonological units are converted into TL letters, or other graphological units. In order to translate the foreign personal and place names to Odia, the nonnative translator Sutton has adopted this transliteration strategy.

(1) SL: Yes, said Christian (Bunyan 1670/1986: 12)

TL: .....khrisTiān nāmaka se jana ..(Sutton 1838: 06) 
(2) SL: Beelzebub is the captain; (Bunyan 1670/1986: 25)

TL: bālājibub nāmaka senāpati (Sutton 1838: 32)

jishāk o jākuba... (Sutton 1838: 325)

(3) SL: ....Encoh, Moses and Elijah, etc (Bunyan 1670/1986 :155)

TL:...... hinok nāmare o mosā nāmare puNi eliya nāmare (Sutton 1838: 329)

\section{Conclusion}

A translator often prefers to bridge the gaps between two texts. In order to translate a text to one's mother tongue, a translator often adopts the linguistic and extra-linguistic translation strategies. Similarly, the non-native Odia translators have adopted the linguistic strategies, literal translation strategy, lexical alteration strategy, deletion, transliteration, exoticism, and cultural transpositions for their translation. Translation strategy is a question of a translator's decision. Since most of the literary texts are considered as metatexts composed of several domain-specific forms and contents, the task of their translators is to consciously look for the equivalent effects and try to solve the problems by adopting different strategies. According to various contexts and situations, textual and meta-textual functions of literature and their equivalence problems motivate the translators to adopt certain translation strategies for making a good translation. These lead the translators to apply the min-max strategy so that equivalent effects can be created and translation fidelity can be achieved to the maximum extent. Since translation is a negotiation between two different linguistic, literary, and cultural texts, in the course of translating some textual materials from one language to another, there may or may not be natural equivalences in TT. In this context, translating extra-linguistic features, such as culture specific words, personal names, place names, religion- specific words and expressions create problems. This situation can only be sorted out by translators either by accepting the transliteration approach or rejecting it. Rejecting transliteration is one way where the translator has to accommodate the SL items faithfully in TL, if possible; and the other way is to fix the SL items in TL through adopting transliteration. Translators often take this decision before translating a text which is called the macro-translation strategy. Usually, translators prefer transliteration strategy to semantic rendering of the personal names and place names in TL. Since the objectives of the SLTs were to promote religious evangelization and second language learning, the translation strategies tried to preserve the religious and pedagogical fidelity rather that textual fidelity in the translated texts.

\section{References}

Arangaden, Chrysostom and John Philipose. 1992. Carey's Legacy of Bible Translation. International Journal of Translation 4(1\&2). 1-18. 
BASU, B. D. 1922. History of Education in India under the Rule of the East India Company ( $2^{\text {nd }}$ edition). Calcutta: Modern Review Office.

BunyAn, JoHN. 1678/1968. The Pilgrim's Progress. Edited by Alexander M. Witherspoon. New York: Washington Square Press.

CAMPBEll, William. 1839. British India. London: Longman.

S. COHN, BERNARD. 1936. Colonialism and its Forms of Knowledge: The British in India. Princeton: Princeton University Press.

CATFORD, J. C. 1965. A Linguistic Theory of Translation: An Essay in Applied Linguistics. Oxford University Press.

CHESTERMAN and WAGNER. 2002. Can Theory Help Translators? Mancester: St. Jerome Publishing.

Chesterman, A. 2005. Problems with Strategies. New Trends in Translation Studies: In Honour of Krisztina Karoly and Agota Foris. Budapest: Akademic Kiado.

Cox, Francis Augustus. 1842. History of the Baptist Missionary Society from 1792 to 1842, 1. London: T. Ward and G \& J. Dyer.

DAS, NilaKANTHA. 2003. Atmajeebanee (Autobiography, third edition). Cuttack: Cuttack Student's Store.

DAS, SISIR KUMAR. 1974. The Shadow of the Cross. New Delhi: Munshiram Manoharlal Publishers Pvt. Ltd.

DAS, SISIR KUMAR. 1991. A History of Indian Literature, Vol. XIII (18001910). New Delhi: Sahitya Akademi.

Delisle, J. and WoODSWORTH, J. (ed.) 1995. Translation through History. Amsterdam: John Benjamin.

Hervery, S. and Higgins, I. 1992. Thinking Translation: A Course in Translation Method: French-English. London: Routledge Tylor \& Francis Group.

IVIR, VLADIMIR. 1987. Procedure and Strategies for the Translation of Culture. In Gideon Toury (ed.), Translation across Cultures. IJAL 13(2). New Delhi: Bahri Publications Pvt.Ltd.

KEARnS, JOHn. 2009. Strategies. In Mona Baker (ed.), The Routledge Encyclopedia of Translation Studies. London: Routledge Tylor \& Francis Group.

LAMBERT, J. and LEFEVERE, A. (eds.) 1993. Translation in the Development of Literatures. Bern: Peter Lang.

LEWIS, P. 2001. Missionary and Language. In Rajend Mesthrie (ed.), Concise Encyclopedia of Sociolinguistics. Amsterdam: Elsevier Science Ltd.

LONG, LYNNE. 2007. History and Translation. In Kuhiwczak and Karin Littau (ed.), A Companion to Translation Studies. Clevedon: Multilingual Matters Ltd.

MAHAPATRA, MAHESh CHANDRA. 1977. Adhunika Sikhya o Orissa (Modern Education and Orissa). Cuttack: Granthamandir. 
Maltby, T. J. 1986. A Practical Handbook of the Uriya or Odiya Language. (reprint). New Delhi: Asian Educational Services.

Mansinha, MaYAdHAR. 1962. History of Oriya Literature. New Delhi: Sahitya Akademi.

MANSINHA, MAYADHAR. 1997. Fhakirmohan Senapati (reprint). New Delhi: Sahitya Akademi.

Marshman, J. C. 1859. The Life and Times of Carey, Marshman and Ward 1. London: Longman.

Mishra, NARENDRANATH. 1998. Nilakantha Das. New Delhi: Sahitya Akademi.

MishrA, SRINIBAS. 1995. Adhunika Odia gadya Sahitya (Modern Odia Prose Literature). Cuttack: Vidyapuri.

Mohanty, JugalKishoR. 1961. William Carey. Cuttack: The Orissa Mission Press.

MolinA, LuCiA, and Hurtado AlibiR, A. 2002. Translation Techniques Revisited: A Dynamic and Functional Apporach. Meta 47(4).

MukHERJEe, AJIT. 2001. Carey William (1761-1834). In John. F. Sawyer \& J. M. Y. Simpson (eds.), Concise Encyclopedia of Language and Religion. Amsterdam: Elsevier.

MUKHERJEE, P. 1964. History of Orissa 06. Cuttack: Utkal University.

NEWMARK, P. 1988. A Textbook of Translation. New York: Prentice Hall.

NIDA, E. A. 1964. Linguistics and Ethnology in Translation Problems. In Dell Hymes (ed.), Language in Culture and Society. Bombay: Allied Publishers Private Limited.

NIDA, EugENE. 1947. Bible Translating: An Analysis of Principles and Procedures. New York: American Bible Society.

NIDA, EUGENE. 1964. Toward a Science of Translating. Leiden: E. J. Brill.

NIDA, A. and C. R. TABER. 1969. The Theory and Practice of Translation. Leiden: E. J. Brill.

NIDA, E. A. 2005. Contexts in Translating. Amsterdam: John Benjamins Publishing Company.

OuYAng, E. 1993. The Transparent Eye: Reflections on Translation, Chinese Literature, and Comparative Poetics. Honolulu: University of Hawaii Press.

SAMANTARAY, NATABARA. 1979. Adhunika Odia Sahitya Bikasara Prusthabhumi. (Development of Modern Odia Literature Foundation). Bhubaneswar: Gangabai Samantaray.

SAMANTARAY, NATABAR. 1983. Odia Sahityara Itihasa (1803-1920) (History of Odia Literature). Bhubaneswar: N. Samantaray (first published in 1964). 
SAMANTARAY, NATABAR. 1993. Oriya Bhasabilopa Eka Spastikarana (Odia Language Abolition: a Clarification). Konark 87. 1-30. Bhubaneswar: Odisha Sahitya Akademi.

SCHUlTE, RAINER and JOHN BIGUENET. (eds.) 1992. Theories of Translation: An Anthology of Essays from Dryden to Derrida. Chicago: University of Chicago Press.

SINGH, JAYANANDA. 1996. Odisare KhisTa Dharmodya o Keteka Adya KrisTanka Jibani (the Rise of Christianity in Odisha and the Lives of some leading Odia Converts). Cuttack: Utkal Christian Sahitya Board.

SHERRING. 1884. The History of Protestant Missions in India. London: Longman.

SHORE, FREDERICK. 1837. Notes on Indian Affairs, 1. London: Longman.

Smith, GeORge. 1935. The Life of William Carey. London: J. M. Dent \& Sons Ltd.

SNEll-Hornby, M. 1995. Translation Studies: An Integrated Approach. Amsterdam: John Benjamins.

St-PIERRE, PAUL. 2005. Translation in an Era of Globalization. In Paul StPierre and Prafulla C. Kar (eds.), In Translation, Reflections, Refractions, Transformations. Delhi: Pencraft International.

ST-PIERRE, PAUL. 2010. Translation in Orissa: Trends in Cultural Interactions. Socio-Cultural Approaches to Translation: Indian and European Perspectives. New Delhi: Excel India Publishes.

SuTton, Amos. 1838. Swargiya Jatrira Brutanata (tr). Cuttack: Orissa General Baptist Missionary Society.

The Holy Bible: Revised Version, Standard American Edition. New York: Thomas Nelson \& Sons.

Trevelyan, Charles E. 1838. The Education of the People of India. London: Longman.

Ullmann, Stephen. 1957. The Principles of Semantics. Oxford. Basil Blackwell \& Mott Ltd.

VINAY, JEAN-PAUl and JEAN DARBELnET. 1995. Comparative Stylistics of French and English. Amsterdam: John Benjamins Publishing Company.

Williams, J. and Chesterman, A. 2002. The Map: A Beginner's Guide to Doing Research in Translation Studies. Manchester: St Jerome.

WindHAUSEN, JOHN D. 1964. The Vernaculars, 1835-1839: A Third Medium for Indian. Education. Sociology of Education 37(3). 254-270.

ZAstoupil, L. and MOIR,M. 1999. The Great Indian Education Debate: Documents Relating to the Orientalist-Anglicist,1781-1843. Richmond: Curzon Press. 